\title{
HUBUNGAN PARTISIPASI MASYARAKAT DENGAN KEBERLANJUTAN EKOLOGI, SOSIAL-BUDAYA DAN EKONOMI DALAM EKOWISATA RELIGI
}

\section{Correlation of Community's Participation with Sustainability of Ecology, Socio-Cultural and Economic in Religious Ecoturism}

\author{
Mohammad Irfan Rachman ${ }^{1)}$ dan Rina Mardiana ${ }^{1)}$ \\ ${ }^{1)}$ Departemen Sains Komunikasi dan Pengembangan Masyarakat, Fakultas Ekologi Manusia, \\ Institut Pertanian Bogor, Darmaga Bogor 16680, Indonesia \\ E-mail: irfanrachman8@gmail.com; rmardiana@apps.ipb.ac.id
}

\begin{abstract}
Community based ecotourism is a rural development through a tourism sector that not only sell natural resources but also contributes to environmental conservation and the active participation of communities as managers. The religious ecotourism of Kampung Batusuhunan is a tourism that prioritizes the conservation of the environment by combining religious culture and communitiy's participation. The objective of this reseach is to analyze the relationship of community participation with sustainability of ecology, socio-cultural and economic used quantitative research methods supported by qualitative data. The results of research showed there is a strong and significant relationship between community participation with socio-cultural sustainability, while community participation with ecology and economic sustainability shows a moderate and significant correlation.
\end{abstract}

Keywords : community's empowerment, co-management, ecotourism, sustainability

\begin{abstract}
ABSTRAK
Ekowisata berbasis masyarakat merupakan pengembangan pedesaan melalui sektor pariwisata yang tidak hanya menjual sumberdaya wisata yang masih alami, namun juga berkontribusi terhadap upaya konservasi lingkungan serta peningkatan partisipasi aktif masyarakat sebagai pengelola. Ekowisata religi Kampung Batusuhunan merupakan pariwisata yang mengedepankan konservasi lingkungan dengan memadukan kebudayaan agama serta partisipasi masyarakat. Penelitian ini bertujuan untuk menganalisis hubungan partisipasi masyarakat dengan keberlanjutan ekologi, sosial-budaya dan ekonomi masyarakat dengan menggunakan metode penelitian kuantitatif yang didukung dengan data kualitatif. Hasil penelitian menunjukkan terdapat hubungan yang kuat dan signifikan antara partisipasi masyarakat dengan keberlanjutan sosial-budaya, sedangkan partisipasi masyarakat dengan keberlanjutan ekologi dan keberlanjutan ekonomi menunjukkan hubungan yang cukup dan signifikan.
\end{abstract}

Kata Kunci : ekowisata, keberlanjutan, pengelolaan, pemberdayaan masyarakat

\section{PENDAHULUAN}

Undang-Undang nomor 4 tahun 1982 tentang ketentuan-ketentuan pokok pengelolaan lingkungan hidup menyatakan, pembangunan berkelanjutan merupakan aktivitas memanfaatkan seluruh sumberdaya, guna meningkatkan kualitas hidup dan kesejahteraan masyarakat manusia. Pembangunan ekonomi daerah yang kuat dan berkelanjutan merupakan sebuah kolaborasi yang efektif antara pemanfaatan sumberdaya, masyarakat dan pemerintah (Satria 2009). Pelaksanaan pembangunan pada dasarnya merupakan upaya memelihara keseimbangan antara lingkungan alami (sumberdaya alam hayati dan non hayati) dan lingkungan binaan (sumberdaya manusia dan buatan), sehingga sifat interaksi maupun interdependensi antar keduanya tetap dalam keserasian yang seimbang (Suwantoro 1997). Dalam konteks ini, pemerintah sebagai regulator berperan strategis dalam mengupayakan kesempatan yang luas bagi masyarakat lokal untuk berpartisipasi penuh dalam setiap aktivitas ekonomi. Salah satu upaya pemanfaatan sumberdaya lokal yang optimal adalah dengan mengembangkan pariwisata menjadi pariwisata berkelanjutan (Ekowisata). Hal tersebut 
dapat direpresentasikan dengan wisata yang tidak terpisahkan dari masyarakat, seperti upaya konservasi, perbedaan kultur atau budaya, dan pemberdayaan ekonomi lokal.

Undang-Undang No. 10 Tahun 2009 tentang Kepariwisataan, menimbang bahwa keadaan alam, flora, dan fauna, sebagai karunia Tuhan Yang Maha Esa, serta peninggalan purbakala, peninggalan sejarah, serta seni dan budaya yang dimiliki bangsa Indonesia merupakan sumberdaya dan modal pembangunan kepariwisataan untuk peningkatan kemakmuran dan kesejahteraan rakyat sebagaimana terkandung dalam Pancasila dan Pembukaan Undang-Undang Dasar Negara Republik Indonesia tahun 1945. Selain itu, pada Undang-Undang No. 10 Tahun 2009 mendefinisikan bahwa kepariwisataan merupakan integral dari pembangunan nasional yang dilakukan secara sistematis, terencana, terpadu, berkelanjutan, dan bertanggung jawab dengan tetap memberikan perlindungan terhadap nilai-nilai agama, budaya yang hidup dalam masyarakat, kelestarian, mutu lingkungan hidup, dan kepentingan nasional. Pembangunan kepariwisataan diperlukan untuk mendorong pemerataan kesempatan berusaha serta mampu menghadapi tantangan perubahan kehidupan lokal, nasional dan global.

Indonesia yang dikenal dengan negara megabiodiversity nomor dua di dunia dengan segala potensi kekayaan alam mampu menjadi daya tarik bagi wisatawan. Memiliki lebih dari 17.000 pulau yang mempunyai potensi wisata alam yang merupkan sektor penting pariwisata dalam menumbuhkan perekonomian Indonesia. Melihat tren pariwisata tahun 2020, perjalanan wisata dunia akan mencapai 1,6 milyar orang, diantaranya 438 juta orang akan berkunjung ke kawasan Asia Pasifik (Harun 2008). Untuk meningkatkan peran kepariwisataan, sektor pariwisata memperoleh prioritas dalam pengembangannya (Sujali 1996). Adanya kebijakan baru pemerintah dibidang kepariwisataan telah menimbulkan rasa optimisme dari pemerintah pusat maupun daerah, serta para stakeholder pengembang pariwisata dan juga masyarakat untuk menjadikan daerah tujuan wisata yang semakin besar.

Saat ini, konsep pariwisata telah banyak dikembangangkan, salah satunya adalah pariwisata berwawasan lingkungan atau biasa disebut ekowisata. Ekowisata muncul dikarenakan banyak ketidakpuasan masyarakat sekitar terhadap wisata alam dan wisata terbuka yang menimbulkan kerusakan ekologi dikarenakan melebihi kapasitas pengunjung di tempat wisata tersebut. Ekowisata merupakan kawasan pelestarian alam yang dikelola dengan sistem Community Based Ecoturism (CBE). CBE merupakan model pengembangan ekowisata berbasis masyarakat dengan melibatkan dan menempatkan masyarakat lokal yang mempunyai kendali penuh langsung dalam manajemen dan pengembangannya, sehingga memberikan kontribusi masyarakat berupa peningkatan kesejahteraan masyarakat lokal dan keberlanjutan kebudayaan lokal (Untari 2009). Hal tersebut sejalan dengan rumusan sembilan agenda prioritas dalam pemerintahan Kabinet Kerja Joko Widodo dan Jusuf Kalla pada periode 2014-2019 yang disebut "NAWACITA" yang tertuang dalam "Jalan Perubahan untuk Indonesia yang Berdaulat, Mandiri, dan Berkepribadian" dengan mengidentifikasi tiga permasalahan pokok Bangsa Indonesia yaitu: (1) merosostnya kewibawaan negara; (2) melemahnya sendi-sendi perekonomian nasional; dan (3) merebaknya intoleransi dan krisis kepribadian bangsa dengan mengusung visi "Terwujudnya Indonesia yang Berdaulat, Mandiri, dan Berkepribadian Berlandaskan Gotong-royong”. Usaha dalam mewujudkan visi tersebut maka dirumuskan sembilan agenda prioritas dalam pemerintahan kedepan yang disebut "NAWACITA". Program tersebut digagas untuk mewujudkan perubahan Indonesia yang berdaulat secara politik, mandiri dengan membangun ekonomi dari pinggiran dengan memperkuat daerah-daerah dan desa dalam kerangka negara kesatuan yang tertuang dalam poin ketiga agenda "NAWACITA".

Peraturan Menteri Dalam Negeri No 33 Tahun 2009 Pasal 3 menegaskan prinsip pengembangan ekowisata meliputi kesesuaian antara jenis serta karakteristik ekowisata dan konservasi yaitu melindungi, mengawetkan, dan memanfaatkan secara lestari sumberdaya alam yang digunakan untuk ekowisata yang mengandung beberapa unsur, seperti ekonomis, yaitu memberikan manfaat untuk masyarakat setempat dan menjadi penggerak pembangunan ekonomi di wilayahnya serta memastikan usaha ekowisata dapat berkelanjutan. Edukasi, yaitu mengandung unsur pendidikan untuk mengubah persepsi seseorang agar memiliki kepedulian, tanggung jawab, dan komitmen terhadap pelestarian lingkungan dan budaya serta memberikan kepuasan dan pengalaman kepada pengunjung. Partisipasi masyarakat, yaitu peran serta masyarakat dalam kegiatan perencanaan, pemanfaatan, dan pengendalian ekowisata dengan menghormati nilai- 
nilai sosial-budaya dan keagamaan masyarakat di sekitar kawasan dan menampung kearifan lokal.

Ekowisata dapat dikembangkan apabila ada suatu pembagian wilayah yang jelas, sehingga tidak hanya penyelenggaraan wisata alam saja yang dapat dilakukan, tetapi juga unsur pelestarian lingkungan melalui pendidikan, perlindungan, penelitian dan konservasi (Yoeti 2004). Salah satu ekowisata yang berperan penting dalam pelestarian ekologi, sosialbudaya dan ekonomi adalah ekowisata religi. Ekowisata tersebut dikelola dengan pendekatan berkelanjutan yang menggunakan konsep "eco" dimana konsep ini mengutamakan aspek konservasi alam dan pemberdayaan masyarakat yang dikaitkan dengan pendekatan spiritualitas atau keyakinan beragama. Pengelolaan ini diarahkan pada kelestarian alam seperti air terjun, goa, makam, candi dan keyakinan budaya masyarakat setempat, kesejahteraan sosial budaya masyarakat serta keberlangsungan pemanfaatan sumber daya yang dikelola secara berkelanjutan.

Pengelolaan ekowisata religi tidak hanya melibatkan pemerintah maupun lembaga kebudayaan dan pariwisata setempat, partisipasi masyarakat juga sangat dibutuhkan. Menurut Slamet (2003), agar tumbuh partisipasi masyarakat, paling tidak ada tiga sarat yang harus dipenuhi, yaitu adanya kesempatan dalam pembangunan, adanya kemampuan untuk memanfaatkan kesempatan tersebut, dan adanya kemauan/motivasi untuk berpartisipasi. Dari hubungan partisipasi masyarakat ini akhirnya dikenal ekowisata berbasis masyarakat, yaitu suatu pengembangan wisata yang mengedepankan aspek lingkungan, sosial budaya (keyakinan) dan ekonomi.

Pengelolaan ekowisata yang mengedepankan partisipasi masyarakat dapat menimbulkan keberlanjutan yang baik bagi masyarakat, seperti keberlanjutan ekologi dimana pengunjung yang datang dapat mengikuti program menanam pohon, belajar bagaimana cara bertani yang baik dan benar serta mampu mendidik masyarakat agar mulai memilah sampah organik maupun non organik. Keberlanjutan sosial-budaya dilihat dari kebiasaan atau adat masyarakat sekitar yang dihormati dan dihargai seperti keramahtamahan masyarakat, larangan dalam berkata di tempat-tempat tertentu sesuai norma masyarakat yang berlaku di sekitar kawasan. Keberlanjutan ekonomi yang dilihat dari kesejahteraan masyarakat setempat dengan memanfaatkan peluang yang ada seperti berjualan makanan khas baik dari hasil pertanian maupun non pertanian dan souvenir di sekitar tempat wisata. Hal tersebut dapat dijadikan sebagai acuan dalam implementasi "NAWACITA" dengan mengembangkan kemandirian ekonomi masyarakat dari pinggiran yang ditemui dalam ekowisata religi Kampung Batusuhunan, Kelurahan Surade, Kabupaten Sukabumi, Jawa Barat, oleh karena itu pertanyaan utama dalam penelitian ini adalah bagaimana hubungan tingkat partisipasi masyarakat dengan keberlanjutan ekologi, sosial-budaya dan ekonomi dalam ekowisata religi di Kampung Batusuhunan.

\section{PENDEKATAN TEORITIS}

\section{Pariwisata, Ekowisata dan Ekowisata Religi}

Menurut Yoeti (1991), pariwisata berasal dari dua kata, yakni "Pari" dan "Wisata". Pari dapat diartikan sebagai banyak, berkali-kali, berputar-putar atau lengkap. Sedangkan wisata dapat diartikan sebagai perjalanan atau bepergian yang dalam hal ini sinonim dengan kata "travel" dalam bahasa Inggris. Atas dasar itu, maka kata "Pariwisata" dapat diartikan sebagai perjalanan yang dilakukan berkali-kali atau berputar-putar dari suatu tempat ke tempat yang lain, yang dalam bahasa Inggris disebut dengan "Tour". Istilah pariwisata berhubungan erat dengan pengertian perjalanan wisata, yaitu sebagai suatu perubahan tempat tinggal sementara seseorang di luar tempat tinggalnya karena suatu alasan dan bukan untuk melakukan yang menghasilkan upah. Dengan demikian dapat dikatakan bahwa perjalanan wisata merupakan suatu perjalanan yang dilakukan oleh seseorang atau lebih dengan tujuan antara lain untuk mendapatkan kenikmatan dan memenuhi hasrat ingin mengetahui sesuatu (Suwantoro 1997).

Dalam perkembangan kepariwisataan secara umum muncul istilah wisata berkelanjutan (ekowisata). Menurut Swarbrooke (1998) pada hakekatnya pariwisata berkelanjutan (ekowisata) harus terintegrasi pada tiga dimensi. Tiga dimensi tersebut adalah dimensi lingkungan, dimensi ekonomi, dan dimensi sosial. Selanjutnya berdasarkan konteks pembangunan berkelanjutan, pariwisata berkelanjutan dapat didefinisikan sebagai pembangunan kepariwisataan yang sesuai dengan kebutuhan wisatawan dengan tetap memperhatikan kelestarian (conservation, environmental dimention), memberi peluang bagi generasi muda untuk memanfaatkan (economic dimention) dan mengembangkannya berdasarkan tatanan sosial (social dimention) yang telah ada. 
Selain mengedepankan keberlanjutan dan konservasi, saat ini ekowisata telah dikembangkan ke berbagai macam jenis, salah satunya ekowisata religi. Pada dasarnya ekowisata religi merupakan sebuah konsep wisata dipadukan dengan kebudayaan agama yang melekat pada masyarakat sekitar wisata. Zhang, Liu, Huang, dan Wang (2007) dalam buku yang berjudul religious tourism and cultural pilgrimage in China perspective mendefinisikan wisata religi sebagai kegiatan atau aktivitas khusus turis yang berorientasi pada kebudayaan atau kepercayaan mereka dengan bantuan lingkungan dan budaya yang masih alami. Kegiatan aktivitas khusus tersebut dilakukan oleh turis untuk beribadah, tamasya, penelitian dan membawa kebudayaan dari pengikut agama, baik yang kepercayaannya kuat maupun awam.

\section{Ekowisata Berbasis Masyarakat}

Yoeti (2008) mengemukakan ekowisata berbasis masyarakat sebagai usaha ekowisata yang menitikberatkan peran aktif masyarakat, hal tersebut didasarkan kenyataan bahwa masyarakat memiliki pengetahuan tentang alam serta budaya yang menjadi potensi dan nilai jual sebagai daya tarik wisata, sehingga pelibatan masyarakat menjadi mutlak. Pola ekowisata berbasis masyarakat adalah dengan mengakui hak masyarakat lokal dalam mengelola kegiatan wisata di kawasan yang mereka miliki secara adat ataupun sebagai pengelola. Dengan adanya pola ekowisata berbasis masyarakat bukan berarti masyarakat akan menjalankan usaha ekowisata sendiri. Implementasi ekowisata perlu dipandang sebagai bagian dari perencanaan pembangunan terpadu yang dilakukan di suatu daerah. Untuk itu, pelibatan para pihak terkait mulai dari level komunitas, masyarakat, pemerintah, dunia usaha dan organisasi non pemerintah diharapkan membangun suatu jaringan serta menjalankan suatu kemitraan yang baik sesuai peran dan keahlian masing masing (WWF Indonesia 2009).

\section{Partisipasi Masyarakat}

Partisipasi merupakan sebuah instrumen untuk mencapai hasil dan dampak program dan kebijakan yang lebih baik, sedangkan dalam argumen demokratis dan pemberdayaan, partisipasi adalah sebuah proses meningkatkan kapasitas individu sehingga menghasilkan sebuah perubahan positif bagi kehidupan. Partisipasi sebagai proses aktif, di mana inisiatif diambil oleh masyarakat sendiri, dibimbing oleh cara berfikir mereka sendiri, dengan menggunakan sarana dan proses (lembaga dan mekanisme) di mana meraka dapat melakukan kontrol secara efektif (Nasdian 2014). Definisi tersebut memberikan pengertian bahwa masyarakat secara mandiri ikut dalam program dan mampu untuk mengelola potensi yang dimiliki dengan usaha sendiri.

Menurut Slamet (2003), agar tumbuh partisipasi, paling tidak ada tiga sarat yang harus dipenuhi, yaitu adanya kesempatan dalam pembangunan, adanya kemampuan untuk memanfaatkan kesempatan tersebut, dan adanya kemauan/motivasi untuk berpartisipasi. Kemudian, Lugiarti (2004) mengemukakan bahwa kemauan ditentukan oleh faktor yang bersifat psikologis individu, seperti motif, harapan, kebutuhan, dan imbalan. Lingkungan pariwisata yang berbasisikan alam, budaya dan warisan secara alami mempunyai keterbatasan dalam mempertahankan kondisinya terhadap fenomena kehidupan yang terus berubah dan berkembang. Kemajuan teknologi dan ilmu pengetahuan memicu perubahan prilaku manusia dalam upaya memenuhi kebutuhan dan keinginannya termasuk kebutuhan untuk bersenang-senang dengan melakukan perjalan yang dalam berbagai kasus menjadi penyebab menurunnya kepariwisataan baik fisik, sosial maupun budaya (Yoeti 2006).

Tingkat partisipasi masyarakat dalam pengelolaan ekowisata berbasis masyarakat dapat diukur dengan tingkatan partisipasi Cohen dan Uphoff (1979). Cohen dan Uphoff (1979) membagi partisipasi ke beberapa tahapan, yaitu sebagai berikut:

1. Tahap pengambilan keputusan, yang diwujudkan dengan keikutsertaan masyarakat dalam rapat-rapat. Tahap pengambilan keputusan yang dimaksud disini yaitu pada perencanaan dan pelaksanaan suatu program.

2. Tahap pelaksanaan yang merupakan tahap terpenting dalam pembangunan, sebab inti dari pembangunan adalah pelaksanaanya. Wujud nyata partisipasi pada tahap ini digolongkan menjadi tiga, yaitu partisipasi dalam bentuk sumbangan pemikiran, bentuk sumbangan materi, dan bentuk tindakan sebagai anggota proyek.

3. Tahap menikmati hasil, yang dapat dijadikan indikator keberhasilan partisipasi masyarakat pada tahap perencanaan dan pelaksanaan proyek. Selain itu, dengan melihat posisi masyarakat sebagai subjek pembangunan, maka semakin besar manfaat proyek dirasakan, berarti proyek tersebut berhasil mengenai sasaran. 
4. Tahap evaluasi, dianggap penting sebab partisipasi masyarakat pada tahap ini merupakan umpan balik yang dapat memberi masukan demi perbaikan pelaksanaan proyek selanjutnya.

\section{Keberlanjutan Ekologi, Sosial-Budaya, dan Ekonomi}

Menurut Salim (1990) pembangunan berkelanjutan bertujuan untuk meningkatkan kesejahteraan masyarakat dan untuk memenuhi kebutuhan aspirasi manusia. Pembangunan berkelanjutan pada hekekatnya ditujukan untuk mencari pemerataan pembangunan antar generasi pada masa kini maupun masa mendatang. Sementara itu Budimanta (2005) menyatakan bahwa pembangunan berkelanjutan adalah suatu cara pandang mengenai kegiatan yang dilakukan secara sistematis dan terencana dalam kerangka peningkatan kesejahteraan, kualitas kehidupan dan lingkungan umat manusia tanpa mengurangi akses dan kesempatan kepada generasi yang akan datang untuk menikmati dan memanfaatkannya. Menurut Direktorat Jendral Cipta Karya (2016) Keberhasilan dari pembangunan berkelanjutan tidak hanya bergantung pada sektor ekonomi, melainkan perlu adanya campur tangan dari pemegang kekuasaan, dalam hal ini pemerintah, guna mengimplementasinya pembangunan berkelanjutan sehingga tercapai pemerataan kesejahteraan. Pembangunan berkelanjutan memiliki tiga pilar utama yang saling berkesinambungan, diantaranya:

1. Pertumbuhan ekonomi, yakni menjaga pertumbuhan ekonomi yang stabil dengan merestrukturisasi sistem produktif untuk menghemat sumber daya dan energi.

2. Keberlanjutan sosial, yakni menjamin keadilan sosial dalam distribusi kekayaan dan pelayanan sosial.

3. Keberlanjutan lingkungan, yakni dengan menjaga lingkungan tempat tinggal agar nyaman dan aman melalui zero emission.

Sejalan dengan Peraturan Pemerintah Pariwisata no 14 tentang Pedoman Destinasi Pariwisata Berkelanjutan Pasal 3 bab 2A, B, dan C (2016) tentang pelestarian lingkungan, sosial budaya, dan pemanfaatan ekonomi lokal meliputi; perlindungan lingkungan sensitif; perlindungan alam liar (flora dan fauna); emisi gas rumah kaca; konservasi energi; pengelolaan air; keamanan air; kualitas air; limbah cair; mengurangi limbah padat; polusi cahaya dan suara, serta transportasi ramah lingkungan. Sementara pelestarian budaya bagi masyarakat dan pengunjung meliputi perlindungan atraksi wisata, pengelolaan pengunjung, perilaku pengunjung, perlindungan warisan budaya. interpretasi tapak dan perlindungan kekayaan intelektual, sedangkan pemanfaatan ekonomi lokal meliputi; pemantauan ekonomi, peluang kerja untuk masyarakat lokal, partisipasi masyarakat, opini masyarakat lokal, akses bagi masyarakat lokal, fungsi edukasi sadar wisata, pencegahan eksploitasi, dukungan untuk masyarakat, dan mendukung usaha lokal dan perdagangan yang adil.

\section{Kerangka Pemikiran}

Timothy (1999) menjelaskan ekowisata berbasis masyarakat merupakan pemahaman yang berkaitan dengan manfaat yang diperoleh oleh masyarakat dan adanya upaya perencanaan pendampingan yang membela masyarakat lokal serta kelompok (stakeholder) yang memiliki ketertarikan atau minat kepada kepariwisataan setempat dan tata kelola kepariwisataan yang memberi ruang kontrol yang lebih besar untuk mewujudkan kesejahteraan masyarakat. Dikatakan sebagai ekowisata karena bentuk wisata yang ditawarkan adalah wisata dengan prinsip konservasi serta keindahan alam yang harus dilestarikan (Fandeli dan Mukhlison 2000)

Ada beberapa jenis ekowisata, salah satunya ekowisata religi. Pengelolaan ekowisata religi membutuhkan partisipasi aktif dari masyarakat setempat, pemerintah dan swasta. Usulan kerangka analisis baru dapat dilihat dalam gambar dibawah ini. Partisipasi Masyarakat menjadi kunci dalam ekowisata religi dengan keberlanjutan ekologi, sosial-budaya dan ekonomi lokal. Dalam kerangka berpikir dijelaskan bahwa tingkat partisipasi masyarakat berhubungan dengan keberlanjutan ekologi, sosial-budaya, dan ekonomi lokal dalam ekowisata religi. Pada variabel keberlanjutan ekologi dapat dilihat dari indikator tingkat kelestarian lingkungan dan tingkat pemanfaatan sumberdaya alam, variabel keberlanjutan sosial-budaya dapat dilihat dari indikator tingkat kelestarian budaya dan tingkat interaksi sosial, dan dari variabel keberlanjutan ekonomi lokal, dapat dilihat dari 
indikator tingkat kemandirian ekonomi lokal dan taraf hidup rumahtangga.

\section{METODE PENELITIAN}

Penelitian yang dilakukan menggunakan data kuantitatif yang didukung dengan data kualitatif. Penelitian ini menggunakan metode penelitian survei. Pemilihan lokasi ini dilakukan secara sengaja (purposive) yaitu Penelitian ini dilakukan di lokasi tempat dikembangannya ekowisata islami Curug Cigangsa, situs sejarah Batu Masigit, RT 14 Kampung Batusuhunan, Kelurahan Surade, Kabupaten Sukabumi, Jawa Barat. Penelitian ini dilakukan pada bulan Maret 2017 sampai April 2017 dengan menggunakan data dari responden dan informan melalui metode sensus dan wawancara mendalam. Populasi sensus dalam penelitian ini sebanyak 35 responden. sedangkan unit analisis yang akan diteliti adalah rumahtangga dengan sasaran penelitian adalah suami/istri/anggota keluarga yang terlibat langsung dalam pengelolaan maupun kegiatan usaha di kawasan ekowisata religi. Hal tersebut dilakukan karena dalam lokasi penelitian di RT 14 hanya terdapat 35 Kepala Keluarga yang ikut serta dalam pengelolaan, pembangunan maupun yang mempunyai usaha di kawasan ekowisata.

Responden diwawancarai sesuai dengan kuesioner yang telah dibuat dan jawabannya dianggap dapat mewakili kondisi dirinya sebagai salah satu anggota rumah tangga di Kampung Batusuhunan.

Data yang diperoleh dari penelitian ini adalah data hasil kuantitatif didukung dengan data kualitatif. Data hasil wawancara diolah secara statistik deskriptif dan diinterpretasikan dengan menggunakan perangkat lunak Microsoft Excel 2010 dan SPSS for Windows versi 23. Kemudian aplikasi SPSS for windows 23 digunakan untuk membantu uji statistik dengan menggunakan Rank Spearman untuk mengkorelasikan dua data yang mempunyai skala ordinal. Hubungan antara dua variabel penulis memberikan kriteria sebagai berikut (Sarwono, 2006):

1. Jika nilai alpha $0:$ Tidak ada korelasi antara dua variabel

2. Jika nilai alpha lebih dari 0 sampai 0.25 : Korelasi sangat lemah

3. Jika nilai alpha lebih dari 0.25 sampai 0.5 : Korelasi cukup
4. Jika nilai alpha lebih dari 0.5 sampai 0.75 : Korelasi kuat

5. Jika nilai alpha lebih dari 0.75 sampai 0.99 : Korelasi sangat kuat

6. Jika nilai alpha 1: Korelasi sempurna

\section{HASIL DAN PEMBAHASAN}

\section{Tahap Perencanaan}

Partisipasi dalam tahap perencanaan diwujudkan dengan keikutsertaan masyarakat dilihat dari inisiasi para peserta untuk berperan aktif dalam mengelola ekowisata yang ada. Inisiatif ini akhirnya di wujudkan dalam kesediaan para masyarakat untuk ikut dalam perencanaan, seperti merencanakan apa saja aturan-aturan yang diberlakukan bagi para pengunjung yang harus dipatuhi. Selain itu, keikutsertaan masyarakat dalam mengikuti rapat juga menjadi indikator dalam pengukuran tingkat partisipasi pada tahap ini. Gambaran mengenai subindikator pengukuran tingkat partisipasi tahap perencanaan dan hasil pengukurannya disajikan dalam Tabel 1.

Tabel 1 Jumlah dan persentase tingkat partisipasi masyarakat pada tahap perencanaan

\begin{tabular}{cccr}
\hline No. & $\begin{array}{c}\text { Tahap } \\
\text { Perencanaan }\end{array}$ & Jumlah & \multicolumn{1}{c}{ Persen } \\
\hline 1. & Rendah & 1 & 3.0 \\
2. & Sedang & 2 & 6.0 \\
3. & Tinggi & 32 & 91.0 \\
\hline Total & & 35 & 100 \\
\hline
\end{tabular}

Tabel 1 menunjukkan bahwa tingkat partisipasi masyarakat ekowisata religi (islami) pada kategori rendah sebanyak 1 orang dengan persentase sebesar 3 persen, pada kategori sedang sebanyak 2 orang dengan persentase 6 persen, pada kategori tinggi sebanyak 32 orang dengan persentase sebesar 91 persen. Partisipasi pada tahap perencanaan diukur dari keikutsertaan dan keaktifan masyarakat dalam mengikuti setiap kegiatan rapat yang diadakan, serta kontribusi dalam memberikan pendapat dan mengambil keputusan secara bersama-sama. Data pada Tabel 1 menunjukkan objek ekowisata yang terdapat di Kampung Batusuhunan berada di RT 14, sehingga seluruh masyarakat RT 14 secara aktif berpartisipasi dalam menanggapi rapat yang diadakan oleh pengelola ekowisata setempat. Selain itu, saat awal pembukaan ekowisata dibentuk suatu 
musyawarah besar yang diikuti oleh sebagian besar masyarakat RT 14.

\section{Tahap Pelaksanaan}

Partisipasi dalam tahap pelaksanaan diwujudkan dengan keikutsertaan dalam pelaksanaan pengelolaan maupun kegiatan usaha di kawasan ekowisata religi (islami). Tahap pelaksanaan meliputi pelaksanaan dalam pengelolaan ekowisata, keikutsertaan dalam setiap kegiatan sosial masyrakat seperti bersih-bersih kampung, kemudian aktif menjadi panitia dalam kegiatan keagamaan seperti acara maulid nabi. Gambaran mengenai subindikator pengukuran tingkat partisipasi tahap pelaksanaan dan hasil pengukurannya disajikan dalam Tabel 2 berikut.

Tabel 2 Jumlah dan persentase tingkat partisipasi masyarakat pada tahap pelaksanaan

\begin{tabular}{cccr}
\hline No. & $\begin{array}{c}\text { Tahap } \\
\text { Pelaksanaan }\end{array}$ & Jumlah & \multicolumn{1}{c}{ Persen } \\
\hline 1. & Rendah & 1 & 3.0 \\
2. & Sedang & 0 & 0.0 \\
3. & Tinggi & 34 & 97.0 \\
\hline Total & & 35 & 100 \\
\hline
\end{tabular}

Tabel 2 menunjukkan bahwa tingkat partisipasi masyarakat (tahap pelaksanaan) ekowisata religi (islami) pada kategori rendah sebanyak satu orang dengan persentase sebesar 3 persen, pada kategori tinggi sebanyak 34 orang dengan persentase sebesr 97 persen. Hal tersebut dapat dilihat dari keikutsertaan dan keaktifan masyarakat dalam memberikan sumbangan pemikiran berupa pendapat mengenai pelaksanaan kegiatan ekowisata seperti memberikan pendapat tentang aturan-aturan yang berlaku bagi masyarakat dan pengunjung, sumbangan tenaga dalam kegiatan bersih bersih di sekitar kawasan ekowisata religi (islami) yang dilakukan semua masyarakat yang ada di RT 14 .

Hasil tingkat partisipasi rendah pada tahap pelaksanaan diperoleh dari adanya satu responden yang memang betul-betul pendatang baru, sehingga masih belum terlalu aktif dalam menyumbang ide, gagasan serta melaksanakan apa yang telah di musyawarahkan walau sudah diikut sertakan dalam daftar anggota pengelola ekowisata islami. Pernyataan ini sesuai dengan penuturan salah satu warga yang mempunyai nilai skor rendah dalam partisipasi tahap pelaksanaan program berikut.

\begin{abstract}
"Saya mah masih baru pindah ke sini mas, memang setiap warga yang pindah kesini di wajibkan ikut serta dalam anggota pengelolaan dan organisasi kemasyarakatan yang ada di $R T$ sini, saya sendiri disini selau ditinggal suami kerja ke Jakarta, dua bulan baru pulang, jadi agak susah kalau ikut kegiatan tentang pengelolaan ekowisata" (Ibu SNT/24 Tahun).
\end{abstract}

\section{Tahap Menikmati Hasil}

Partisipasi dalam tahap menikmati hasil diwujudkan dengan keikutsertaan masyarakat dalam menmanfaatkan hasil dari adanya pelaksanaan kegiatan ekowisata dari wisatawan yang berkunjung. Dalam penelitian ini tingkat partisipasi pada tahap menikmati hasil dapat dilihat dari bagaimana masyarakat memanfaatkan hasil yang didapatkan setelah dibukanya ekowisata sejak 2013. Selain itu, tingkat partisipasi pada tahap menikmati hasil juga dapat dilihat dari pengetahuan, merasakan manfaat dalam menjalankan pengelolaan dan usaha yang dimiliki masyarakat. Gambaran mengenai subindikator pengukuran tingkat partisipasi tahap menikmati hasil dan hasil pengukurannya disajikan Tabel 3 berikut.

Tabel 3 Jumlah dan persentase tingkat partisipasi masyarakat pada tahap menikmati hasil

\begin{tabular}{cccr}
\hline No. & $\begin{array}{c}\text { Tahap Menikmati } \\
\text { Hasil }\end{array}$ & Jumlah & Persen \\
\hline 1. & Rendah & 1 & 3.0 \\
2. & Sedang & 1 & 3.0 \\
3. & Tinggi & 33 & 94.0 \\
\hline Total & & 35 & 100 \\
\hline
\end{tabular}

Tabel 3 menunjukkan bahwa tingkat partisipasi masyarakat dalam tahap menikmati hasil tegolong dalam tingkat partispasi rendah sebanyak 1 orang dengan persentase sebanyak 3 persen. Sedangkan tingkat partisipasi sedang sebanyak 1 orang dengan persentase sebesar 3 persen dan tingkat partisipasi tinggi sebanyak 33 orang dengan persentase sebesar 94 persen. Kegiatan menikmati hasil dilihat dari batas kurun waktu empat tahun setelah dibukanya ekowisata yang memberi dampak pertumbuhan ekonomi masyarakat dengan adanya pengelolaan berupa biaya tiket masuk sebesar Rp 3000/orang, biaya parkir Rp 5000 untuk motor, Rp 10000 untuk mobil dan adanya bantuan-bantuan dari pemerintah kabupaten dengan PNPM Mandiri. 


\begin{abstract}
"Kalo dibilang menikmati hasil dari adanya ekowisata sih secara umum semua warga disini menikmati ya, apalagi adanya pemungutan retribusi untuk pengunjung seperti biaya masuk, parkir itu nantinya 70\% masuk ke kas $R T$, saat lebaran dikumpulkan lalu dibagikan ke semua KK yang ada di RT 14, kalo masih ada sisa lebih ikut dibagikan ke RT tetangga, biasanya dapet bagian paling 20 sampai 30 ribu per orang. (Pak MRZ/27 Tahun).
\end{abstract}

\section{Tahap Evaluasi}

Partisipasi dalam tahap evaluasi diwujudkan dengan keikutsertaan masyarakat (pengelola maupun anggota) dalam memberikan umpan balik terhadap suatu aturan yang telah dijalankan setiap tiga bulan sekali. Dalam peneitian ini tingkat partisipasi pada tahap evaluasi dilihat dari keterlibatan masyarakat dalam melakukan pengawasan dan memberikan respon terhadap apa yang telah tercapai maupun yang belum tercapai, sehingga terus dilakukan perbaikan dari waktu ke waktu. Gambaran mengenai sub-indikator pengukuran tingkat partisipasi tahap evaluasi dan hasil pengukurannya disajikan dalam Tabel 4 berikut.

Tabel 4 Jumlah dan persentase tingkat partisipasi masyarakat pada tahap evaluasi

\begin{tabular}{cccr}
\hline No. & Tahap Evaluasi & Jumlah & Persen \\
\hline 1. & Rendah & 2 & 6.0 \\
2. & Sedang & 3 & 9.0 \\
3. & Tinggi & 30 & 85.0 \\
\hline Total & & 35 & 100 \\
\hline
\end{tabular}

Tabel 4 menunjukkan bahwa tingkat partisipasi masyarakat ekowisata religi (islami) pada tahap evaluasi yang tergolong dalam kategori rendah sebanyak 2 orang dengan persentase 6 persen, pada kategori sedang sebanyak 3 orang dengan persentase 9 persen, pada kategori tinggi sebanyak 30 orang dengan persentase sebesar 85 persen. Partisipasi pada tahap evaluasi dilihat dari keikutsertaan masyarakat dalam kegiatan monitoring, menilai keberhasilan dan evaluasi selanjutnya. Selain itu, keaktifan masyarakat dalam memberikan kritik dan saran yang bertujuan untuk perbaikan aturan selanjutnya juga menjadi indikator pengukuran tingkat partisipasi dalam tahap ini. Dalam penelitian ini, kegiatan evaluasi dibedakan menjadi dua bentuk. Pertama, evaluasi pelaksanaan kegiatan pengelolaan yang dilaksanakan oleh kelompok pengelola inti secara langsung. Kedua, adalah evaluasi mandiri yang dilakukan oleh masyarakat atau anggota pengelola. Substansi evaluasi yang dilakukan oleh pengelola inti ada dua. pertama mengarah pada evaluasi dampak dan manfaat ekowisata secara lebih luas kepada masyarakat. Kedua melihat sejauh mana kepuasan wisatawan terhadap keramahtamahan masyarakat sekitar kawasan serta penilaian masyarakat sendiri tentang wisatawan yang datang dengan memberikan angket kritik dan saran. Namun, wujud partisipasi masyarakat pada kedua bentuk evaluasi itu adalah sama, yaitu melakukan pengawasan, memberikan informasi, kritik dan saran.

\section{Tingkat Partisipasi Masyarakat Kampung Batusuhunan RT 14}

Terdapat empat komponen yang diukur dalam pengukuran tingkat partisipasi. Keempat komponen tersebut adalah partisipasi pada tahap perencanaan, partisipasi pada tahap pelaksanaan, partisipasi pada tahap menikmati hasil dan partisipasi pada tahap evaluasi. Terdapat beberapa pertanyaan untuk setiap tahapan yang kemudian dijumlahkan dalam seluruh tahap partisipasi, total seluruh pertanyaan tersebut yaitu 12 pertanyaan dan dibagi ke dalam tiga kategori yaitu rendah (12-15), sedang (16-20) dan tinggi (2124). Jumlah dan Persentase Responden berdasarkan tingkat partisipasi masyarakat dalam ekowisata religi (islami) disajikan dalam Tabel 21 di bawah ini..

Tabel 5 Jumlah dan persentase tingkat partisipasi masyarakat Kampung Batusuhunan RT 14

\begin{tabular}{cccr}
\hline No. & Tahap Evaluasi & Jumlah & \multicolumn{1}{c}{ Persen } \\
\hline 1. & Rendah & 1 & 3.0 \\
2. & Sedang & 0 & 0.0 \\
3. & Tinggi & 34 & 97.0 \\
\hline Total & & 35 & 100 \\
\hline
\end{tabular}

Tabel 21 menunjukkan bahwa tingkat partisipasi masyarakat sekitar ekowisata termasuk dalam kategori tinggi, dengan persentase 97 persen. Namun, satu responden memiiki tingkat partisipasi yang tergolong rendah, yaitu sebesar 3 persen. Hasil pengukuran tingkat partisipasi yang tergolong pada kategori tinggi menunjukkan bahwa partisipasi masyarakat memiliki peran dalam keberlangsungan ekowisata. Wujud partisipasi responden dalam keberlangsungan ekowisata dapat dilihat pada semua tahapan partisipasi. Walaupun sebaran partisipasi pada setiap tahapnya tidak merata. Hal tersebut disebabkan karena tidak semua responden yang ikut serta dalam kegiatan perencanaan hingga evaluasi 
berpartisipasi secara aktif. Masih ada keengganan mengemukakan pendapat, ide, kritik dan saran ataupun memberikan sumbangan masukan materi dan tenaga.

Faktor lain yang memengaruhi tingkat partisipasi adalah kesempatan yang tersedia bagi masyarakat untuk berpartispasi. Struktur pengelolaan ekowisata yang ada di Kampung Batusuhunan serta merta tidak seluruh kampung, namun hanya RT 14 saja yang menjadi pengelola inti dan anggota serta kegiatan usaha lainnya di kawasan ekowisata. Hal tersebut dikarenakan segala potensi yang ada di Kampung Batusuhunan terletak di RT 14 sehingga yang benar benar terkena dampak besar secara langsung adalah warga RT 14. Sementara 4 RT lainnya tidak ada yang ikut berpartisipasi sama sekali.

"Kalo ditanya partisipasi, semua masyarakat yang ada di RT 14 bisa dibilang semua ikut berpartisipasi. Akan tetapi hal tersebut terkadang memunculkan kecemburuan bagi RT lainnya, karena nama ekowistanya memakai nama Kampung Batusuhunan, ini nama kampung kan bukan RT 14 saja, akan tetapi berhubung semua potensi letaknya di RT 14 jadi masyarakat luar tannya pas masuk gapura yang ada plank selamat datang di ekowisata islami, itu baru masuk Kampung Batusuhunan. Ya harapan saya sih sebagai ketua $R W$ yang udah sering denger keluhan dari warga di $R T$ lainnya walau hanya omongan saja, pemerintah atau dinas pariwisata bisa mengeluarkan kebijakan yang meguntungkan buat Kampung Batusuhunan keseluruhan RT, sehingga semua bisa merasakan manfaatnya dan ekowisata pun ruang lingkupnya jadi lebih besar dan berkembang." (Pak DED/ Ketua RW 08 / 46 Tahun)

\section{Keberlanjutan Ekologi, Sosial-Budaya, dan Ekonomi}

\section{Tingkat Keberlanjutan Ekologi}

Tingkat keberlanjutan ekologi diukur berdasarkan dua sub indikator, yaitu tingkat kelestarian lingkungan dan pemanfaatan sumberdaya alam. Jumlah dan persentase rumahtangga responden berdasarkan tingkat keerlanjutan ekologi dapat dilihat dalam Tabel 6 .

Tabel 6 menunjukkan bahwa tingkat keberlanjutan ekologi pada masyarakat di sekitar kawasan ekowisata dominan tergolong pada tingkat keberlanjutan yang tinggi, dengan persentase sebanyak 68.6 persen. Sedangkan tingkat keberhasilan sedang memiliki persentase sebesar 28.4 persen dan tingkat keberhasilan rendah memiliki persentase sebesar 3 persen.

Tabel 6 Jumlah dan persentase tingkat keberlanjutan ekologi Kampung Batusuhunan RT 14

\begin{tabular}{ccrr}
\hline No. & $\begin{array}{c}\text { Tingkat } \\
\text { Keberlanjutan } \\
\text { Ekologi }\end{array}$ & Jumlah & Persen \\
\hline 1. & Rendah & 1 & 3.0 \\
2. & Sedang & 10 & 28.4 \\
3. & Tinggi & 24 & 68.6 \\
\hline Total & & 35 & 100 \\
\hline
\end{tabular}

Hasil pengukuran tingkat keberlanjutan ekologi yang tergolong tinggi menunjukkan bahwa kondisi kebersihan dan pemanfaatan sumberdaya alam oleh masyarakat tergolong cukup baik. Secara umum, peningkatan sarana dan prasarana kebersihan mengacu pada banyaknya tempat pemilahan sampah yang ada di kawasan ekowisata dan di depan rumah warga, adanya tempat saluran pembuangan air limbah dan pembuatan septiteng, adanya toilet umum yang nyaman dan bersih untuk dipakai para pengunjung ekowisata maupun warga setempat. Pernyataan ini sesuai dengan penuturan salah dua responden berikut.

\begin{abstract}
"Sewaktu ekowisata belum dibuka untuk umum dulu banyak sekali sampah yang berserakan, dan warga juga kadang masih ada buang sampah disungai, tapi berkat bantuan dari PLPBK kan mereka menyediakan sampah di titik tertentu sebanyak 5 titik, dan juga ada penyadaran dari pemerintah tentang kebersihan yang sekaligus dibangun toilet umum dengan air bersih" (Pak DAS/ 40 Tahun).
\end{abstract}

\section{Tingkat Keberlanjutan Sosial-Budaya}

Tingkat keberlanjutan budaya diukur berdasarkan dua sub indikator, yaitu tingkat kelestarian budaya dan interaksi sosial. Jumlah dan persentase rumahtangga responden berdasarkan tingkat keerlanjutan budaya dapat dilihat dalam tabel 7 berikut. 
Tabel 7 Jumlah dan persentase tingkat keberlanjutan sosial-budaya Kampung Batusuhunan RT 14

\begin{tabular}{cccr}
\hline No. & $\begin{array}{c}\text { Tingkat } \\
\text { Keberlanjutan } \\
\text { Sosial-Budaya }\end{array}$ & Jumlah & Persen \\
\hline 1. & Rendah & 0 & 0.0 \\
2. & Sedang & 1 & 3.0 \\
3. & Tinggi & 34 & 97.0 \\
\hline Total & & 35 & 100 \\
\hline
\end{tabular}

Tabel 7 menunjukkan bahwa tingkat keberlanjutan sosial-budaya masyarakat di sekitar kawasan ekowisata tergolong pada tingkat keberlanjutan tinggi, dengan persentase sebanyak 97 persen. Sedangkan tingkat keberlanjutan sedang memiliki persentase sebesar 3 persen.

Hasil pengukuran tingkat keberlanjutan sosialbudaya yang tergolong tinggi ini menunjukkan bahwa kondisi sosial di lingkungan responden tergolong baik. Hal tersebut dilihat dari pengetahuan dan keaktifan masyarakat dalam mengikuti kegiatan maupun ke organisasian kelompok masyarakat. Tingginya rasa peduli antar sesama warga dalam mengikuti kegiatan gotong royong dalam membersihkan lingkungan serta memelihara situs sejarah Batu Masigit secara bersama-sama menjadi tolak ukur mengapa persentase tingkat keberlanjutan sosial-budaya masyarakat tinggi. Tingkat keberlanjutan sosial-budaya juga diukur dengan melihat hubungan baik yang terjalin antara masyarakat sekitar kawasan ekowisata dengan pengunjungnya. Hubungan baik yang terjalin tersebut membuat kesan kepada pengunjung khususnya wisatawan asing bahwa masyarakat sekitar ekowisata mempunyai budaya yang sangat ramah dan saling mengerti satu sama lain.

"Dulu sewaktu masih ada wisatawan asing yang sering berkunjung, ntah itu dari amerika, jerman, prancis, mereka selalu membawa penerjemah sendiri, sewaktu ketika mereka membutuhkan makan, tempat istirahat dll kami warga disini melayani, kita selalu menawarkan mau makan apa dsb, ketika besoknya para wisatawan ini mau pulang, mereka bercerita banyak tentang kehidupan di negara mereka tidak seperti seramah disini, setelah itu mereka pulang, mereka ngasih kita uang asing, kita gabisa nerima gitu aja, warga sini mah gamau punya hutang balas budi jadi kami ngasih sesuatu buat kenang-kenangan ke mereka "(Ibu AAP/50 Tahun).

\section{Tingkat Keberlanjutan Ekonomi}

Tingkat keberlanjutan ekonomi diukur berdasarkan dua sub indikator, yaitu tingkat kemandirian ekonomi lokal dan taraf hidup. Jumlah dan persentase rumahtangga responden berdasarkan tingkat keerlanjutan budaya dapat dilihat dalam tabel 8 berikut.

Tabel 8 Jumlah dan persentase tingkat keberlanjutan sosial-budaya Kampung Batusuhunan RT 14

\begin{tabular}{ccrr}
\hline No. & $\begin{array}{c}\text { Tingkat } \\
\text { Keberlanjutan } \\
\text { Ekonomi }\end{array}$ & Jumlah & Persen \\
\hline 1. & Rendah & 11 & 31.4 \\
2. & Sedang & 21 & 60.0 \\
3. & Tinggi & 3 & 8.6 \\
\hline Total & & 35 & 100 \\
\hline
\end{tabular}

Tabel 8 menunjukkan bahwa tingkat keberlanjutan ekonomi di tempat ekowisata religi (islami) tergolong pada tingkat keberlanjutan ekonomi rendah sebanyak 11 orang atau sebesar 31.4 persen, kategori sedang sebanyak 21 orang atau 60 persen, kategori tinggi sebanyak 3 orang atau sebesar 8.6 persen. Hasil pengukuran tingkat keberlanjutan ekonomi yang tergolong sedang ini disebabkan tingginya nilai kemandirian ekonomi lokal masyarakat dengan rendahnya nilai taraf hidup masyarakat. Meski demikian, adanya nilai kemandirian ekonomi lokal yang tinggi belum terdapat perubahan di tingkat taraf hidup.

Beberapa faktor penyebab hal tersebut adalah. Pertama, tingkat keberhasilan usaha yang dialami oleh masyarakat berbeda-beda. Keberhasilan usaha masyarakat, dipengaruhi oleh kemampuan mengelola dana pinjaman dari PNPM Mandiri secara efisien dan memiliki kaitan yang erat dengan status keberlangsungan usaha. Kedua hanya beberapa responden yang memiliki pekerjaan di sektor ekowisata akan tetapi hanya sekedar pekerjaan sampingan untuk menambah pendapatan responden. Ketiga terdapat ketidakseimbangan antara penghasilan yang didapat dengan pengeluaran yang dikeluarkan oleh responden. 
"Sebenernya sudah pernah ada pelatihan tentang usaha masyarakat dari pemerintah setempat untuk meramaikan tempat ekowisata, tapi pelatihan yang dikasih cuma satu kali. Satu kali itu juga kalau langsung mengerti. Namanya juga saya enggak sekolah $A$ ', jadi kalo yang gitu-gitu engga cepat paham. Maunya ada pelatihan-pelatihan lagi dan kalau bisa mah bisa konsultasi gitu sekalian. Apalagi usaha disini mah masih belum pake embelembel logo A, pake sertifikasi bpom atau halal aja susah karena katanya pas pelatihan harus bayar 2 sampe 3 juta buat kayak gitu doang" (Ibu SAR/68 Tahun).

\section{Hubungan Tingkat Partisipasi Masyarakat dengan Tingkat Keberlanjutan Ekologi}

Masyarakat merupakan subjek penting dalam pembangunan pedesaan yang berkelanjutan. Hal tersebut erat kaitanya dengan salah satu komponen keberlanjutan itu sendiri yaitu ekologi. Kondisi ekologi merupakan salah satu unsur paling utama dalam daya tarik ekowisata. Baik buruknya suatu kondisi ekologi tergantung kepada masyarakat itu sendiri. Untuk itu partisipasi masyarakat dalam menjaga dan melestarikan ekologi disekitar ekowisata sangat dibutuhkan. Hubungan antara tingkat partisipasi masyarakat dengan tingkat keberlanjutan ekologi dalam ekowisata religi ditunjukkan oleh Tabel 9.

Tabel 9 Jumlah dan persentase responden berdasarkan hubungan tingkat partisipasi dengan tingkat keberlanjutan ekologi

\begin{tabular}{|c|c|c|c|c|c|c|c|c|c|}
\hline \multirow{3}{*}{ No } & \multirow{3}{*}{$\begin{array}{l}\text { Tingkat Partisipasi } \\
\text { Masyarakat }\end{array}$} & \multicolumn{6}{|c|}{ Tingkat Keberlanjutan Ekologi } & \multirow{2}{*}{\multicolumn{2}{|c|}{ Total (\%) }} \\
\hline & & \multicolumn{2}{|c|}{ Rendah } & \multicolumn{2}{|c|}{ Sedang } & \multicolumn{2}{|c|}{ Tinggi } & & \\
\hline & & $\mathrm{n}$ & $\%$ & $\mathrm{n}$ & $\%$ & $\mathrm{n}$ & $\%$ & $\mathrm{n}$ & $\%$ \\
\hline 1. & Rendah & 1 & 100,0 & 0 & 0.0 & 0 & 0.0 & 1 & 100.0 \\
\hline 2. & Sedang & 0 & 0.0 & 1 & 100.0 & 0 & 0.0 & 2 & 100.0 \\
\hline 3. & Tinggi & 0 & 0.0 & 9 & 27.3 & 24 & 72.7 & 33 & 100.0 \\
\hline & Total & 1 & 1.1 & 10 & 31.4 & 24 & 68.5 & 35 & 100.0 \\
\hline
\end{tabular}

Secara keseluruhan, tingkat partisipasi yang dimiliki masyarakat terhadap tingkat keberlanjutan ekologi dominan tinggi dengan nilai 68.5 persen. Hal tersebut menunjukkan bahwa semakin tinggi tingkat partisipasi masyarakat, maka semakin tinggi pula tingkat keberlanjutan ekologi. Adapun perolehan nilai pada tingkat partisipasi tinggi dengan keberlanjutan ekologi sedang dengan nilai 27.3 persen. Hal ini disebabkan oleh dua faktor, yang pertama adalah pada saat kegiatan musyawarah tentang ekowisata, baik perencanaan hingga evaluasi masih terdapat masyarakat yang tidak hadir dan sungkan untuk memberikan pendapatnya. Kedua, kesadaran masyarakat akan kebersihan hanya sebatas umum saja, seperti dilarang membuang sampah sembarangan. Masih banyak masyarakat yang belum mengerti secara keseluruhan akan fungsi tempat sampah yang dipilah, sehingga masyarakat sekitar ekowisata membuang semua sampah yang masih kosong tanpa memperdulikan apakah jenis sampah itu termasuk organik, non organik, dan residu.
Hasil uji korelasi dengan menggunakan rank spearman menunjukkan, hubungan partisipasi masyarakat dengan keberlanjutan ekologi memiliki nilai signifikansi 0.005 dengan taraf $\alpha(0.05)$ hal tersebut menunjukan bahawa nilai signifikansi lebih kecil dari nilai $\alpha$. Sedangkan nilai koefisien korelasi sebesar $+0.431 *$ berarti berada pada 0.25 sampai 0.5 artinya korelasi cukup. Jadi hubungan tingkat partisipasi masyarakat dengan tingkat keberlanjutan ekologi dalam ekowisata religi (islami) memiliki hubungan cukup. Dapat disimpulkan terdapat korelasi yang signifikan antara tingkat partisipasi masyarakat dengan tingkat keberlanjutan ekologi.

\section{Hubungan Tingkat Partisipasi Masyarakat dengan Tingkat Keberlanjutan Sosial-Budaya}

Salah satu faktor penting lainnya dalam keberhasilan pengembangan ekowisata berbasis masyarakat adalah keberadaan unsur sosial-budaya masyarakat itu sendiri. Dalam ekowisata religi, aturan-aturan yang berlaku di masyarakat sangat kental dengan 
keyakinan beragama, yaitu agama Islam, penetapan awal dibukanya tempat ekowisata untuk umum harus mempertimbangkan kebiasaan masyarakat, adatistiadat serta nilai-nilai maupun norma masyarakat itu sendiri.

Partisipasi masyarakat dengan keberlanjutan sosialbudaya masing-masing memiliki indikator yang dijadikan sebagai alat pengukuran bagi responden yang disajikan dalam sebuah data dan kemudian diinterpretasikan. Hubungan antara tingkat partisipasi masyarakat dengan tingkat keberlanjutan sosial-budaya dalam ekowisata religi (islami) ditunjukkan oleh Tabel 10.

Tabel 10 Jumlah dan persentase responden berdasarkan hubungan tingkat partisipasi dengan tingkat keberlanjutan sosial-budaya

\begin{tabular}{cccccccc}
\hline & \multirow{2}{*}{ No } & Tingkat Partisipasi & \multicolumn{6}{c}{ Tingkat Keberlanjutan Sosial-Budaya } \\
\cline { 3 - 8 } & Masyarakat & \multicolumn{2}{c}{ Sedang } & \multicolumn{3}{c}{ Tinggi } & \multicolumn{2}{c}{ Total } \\
\cline { 3 - 9 } & & $\mathrm{n}$ & $\%$ & $\mathrm{n}$ & $\%$ & $\mathrm{n}$ & $\%$ \\
\hline 1. & Rendah & 1 & $\mathbf{1 0 0 . 0}$ & 0 & 0.0 & 1 & 100.0 \\
\hline 2. & Sedang & 1 & $\mathbf{1 0 0 . 0}$ & 0 & 0.0 & 1 & 100.0 \\
\hline 3. & Tinggi & 2 & 6.1 & 31 & 93.9 & 33 & 100.0 \\
\hline & Total & 4 & 11.5 & 31 & 88.5 & 35 & 100.0 \\
\hline
\end{tabular}

Hasil tabulasi silang pada Tabel 32 menunjukkan adanya hubungan tingkat partisipasi masyarakat dengan keberlanjutan sosial-budaya. Berdasarkan Tabel 32 dapat dilihat dari jumlah persentase tingkat partisipasi masyarakat sedang, maka tingkat keberlanjutan sosial-budayanya pun cenderung sedang dengan nilai sebesar 100 persen. Sedangkan jika tingkat partisipasi tinggi, maka tingkat keberlanjutan sosial-budayanya juga tinggi dengan nilai sebesar 93.9 persen. hal tersebut menunjukkan bahwa semakin tinggi tingkat partisipasi masyarakat, maka semakin tinggi pula tingkat keberlanjutan sosial-budaya.

Hasil uji korelasi dengan menggunakan rank spearman menunjukkan hubungan tingkat partisipasi dengan keberlanjutan sosial-budaya memiliki nilai signifikansi 0.000 yang berarti lebih kecil dari $\alpha$ (0.05). Sedangkan nilai koefisien dari hasil uji korelasi tersebut yaitu 0.675 . Jika dilihat dari aturan nilai koefisien uji korelasi, maka nilai tersebut masuk ke dalam kategori hubungan kuat, yaitu $>0.5-0.75$. Maka dapat disimpulkan terdapat korelasi yang signifikan antara tingkat partisipasi masyarakat dengan tingkat keberlanjutan sosial-budaya.

Berdasarkan observasi dilapang, diketahui bahwa masyarakat sekitar ekowisata sangat menjunjung tinggi nilai-nilai kekeluargaan, keberagaman serta gotong-royong. Terlihat dari keikutsertaan masyarakat dalam membantu saudara atau tetangga yang sedang mempunyai hajat atau yang sedang mengalami musibah. Nilai keberagaman meliputi aturan-aturan islami yang dibuat bukan berarti orang selain islam tidak boleh masuk, melainkan untuk lebih menghargai masyarakat sekitar. Sedangkan kegiatan gotong royong meliputi kegiatan kemasyarakatan seperti acara keagamaan dan kerja bakti dari mulai perencanaan hingga evaluasi kegiatan, masyarakat banyak yang ikut berpartisipasi. Selain itu masyarakat sekitar ekowisata juga memiliki kesadaran untuk melestarikan budaya seperti menjaga mitos "Batu Masigit", "Eyang Santri Dalem" dan "Unuk Tengah" sebagai keunikan cerita atau mitos budaya setempat.

\section{Hubungan Tingkat Partisipasi Masyarakat dengan Tingkat Keberlanjutan Ekonomi}

Partisipasi masyarakat dalam pengelolaan ekowisata sangat erat kaitannya dengan salah satu unsur keberlanjutan dalam pembangunan, yaitu ekonomi. Pada dasarnya, pengelolaan ekowisata merupakan peluang (opportunities) bagi masyarakat sekitar ekowisata dalam membuka lapangan kerja baru, seperti membuka warung kuliner khas, toko souvenir yang menjual beraneka macam pernak-pernik hingga menjadi pemandu wisata. Partisipasi masyarakat dengan keberlanjutan ekonomi masing-masing memiliki indikator yang dijadikan sebagai alat pengukuran bagi responden yang kemudian disajikan dalam sebuah data untuk selanjutnya diinterpretasikan. Hubungan antara tingkat partisipasi masyarakat dengan tingkat keberlanjutan 
ekonomi dalam ekowisata religi (islami) ditunjukkan

oleh Tabel 11.

Tabel 11 Jumlah dan persentase responden berdasarkan hubungan tingkat partisipasi dengan tingkat keberlanjutan ekonomi

\begin{tabular}{|c|c|c|c|c|c|c|c|c|c|}
\hline \multirow{3}{*}{ No } & \multirow{3}{*}{$\begin{array}{l}\text { Tingkat Partisipasi } \\
\text { Masyarakat }\end{array}$} & \multicolumn{6}{|c|}{ Tingkat Keberlanjutan Ekonomi } & \multirow{2}{*}{\multicolumn{2}{|c|}{ Total $(\%)$}} \\
\hline & & \multicolumn{2}{|c|}{ Rendah } & \multicolumn{2}{|c|}{ Sedang } & \multicolumn{2}{|c|}{ Tinggi } & & \\
\hline & & $\mathrm{n}$ & $\%$ & $\mathrm{n}$ & $\%$ & $\mathrm{n}$ & $\%$ & $\mathrm{n}$ & $\%$ \\
\hline 1. & Rendah & 1 & 100,0 & 0 & 0.0 & 0 & 0.0 & 1 & 100.0 \\
\hline 2. & Sedang & 1 & 100.0 & 0 & $\mathbf{0 . 0}$ & 0 & 0.0 & 1 & 100.0 \\
\hline 3. & Tinggi & 9 & 27.2 & 21 & 63.6 & 3 & 9.2 & 33 & 100.0 \\
\hline & Total & 10 & 31.4 & 21 & 60.0 & 3 & 8.6 & 35 & 100.0 \\
\hline
\end{tabular}

Hasil tabulasi silang pada tabel 33 menunjukkan bahwa tingkat partisipasi pada kategori rendah memiliki hubungan dengan keberlanjutan ekonomi pada kategori rendah, dengan nilai 100 persen. Kemudian, pada kategori tingkat partisipasi sedang memiliki hubungan dengan keberlanjutan ekonomi pada kategori sedang dengan nilai 100 persen. Sedangkan, tingkat partisipasi pada kategori tinggi memiliki hubungan dengan keberlanjutan ekonomi pada kategori sedang dengan nilai sebesar 63.6 persen. Hal tersebut menunjukkan bahwa semakin masyarakat meningkatkan partisipasi mereka, maka semakin meningkat pula tingkat keberlanjutan ekonomi.

Hasil uji korelasi dengan menggunakan rank spearman, menunjukkan, hubungan tingkat partisipasi dengan keberlanjutan ekonomi memiliki nilai signifikansi 0.024 dengan taraf $\alpha$ yaitu $(0.05)$. Nilai ini lebih kecil dari taraf nyata 5 persen. Sedangkan nilai koefisien dari hasil uji korelasi tersebut yaitu $+0.337^{*}$. Jika dilihat dari aturan nilai koefisien uji korelasi, maka nilai tersebut masuk ke dalam kategori $>0.25-0.5$ yaitu termasuk korelasi cukup. Dengan demikian dapat disimpulkan bahwa terdapat korelasi yang signifikan antara tingkat partisipasi masyarakat dengan tingkat keberlanjutan ekonomi.

Berdasarkan observasi lapang, diketahui bahwa sebagian masyarakat sekitar ekowisata memanfaatkan potensi lokal melalui kepemilikan usaha yaitu usaha warung kuliner, usaha homestay, jasa katering, serta usaha pemandu wisata. Akan tetapi hal tersebut masih belum terdapat perubahan taraf hidup masyarakat sekitar ekowisata. Hal tersebut didukung hasil penelitian yang dilakukan oleh Emma Hijriati pada tahun 2013, dimana ekowisata yang sudah berjalan sejak tahun 2010, perubahan taraf hidup belum dapat dirasakan secara signifikan oleh masyarakat Kampung Batusuhunan.

\section{SIMPULAN DAN SARAN}

\section{Simpulan}

Berdasarkan hasil penelitian yang telah dikemukakan sebelumnya, dapat dibuat beberapa kesimpulan sebagai berikut.

1.Berdasarkan penelitian ini ditemukan bahwa terdapat hubungan cukup antara tingkat partisipasi masyarakat dengan keberlanjutan ekologi yang ada di sekitar kawasan ekowisata religi (islami) Kampung Batusuhunan. Hal tersebut ditunjukkan dengan tingginya partisipasi masyarakat untuk selalu menjaga kebersihan, memanfaatkan sumber daya yang ada di lingkungan sekitar serta turut melestarikannya. Walaupun begitu kesadaran masyarakat sekitar kawasan ekowisata dengan lingkungan di tingkat lebih lanjut masih kurang, hal tersebut dapat dibuktikan dengan tidak terdapat tempat pembuangan akhir sampah, sehingga sampah yang sudah penuh dibakar begitu saja sehingga menimbulkan polusi udara.

2.Berdasarkan penelitian ini ditemukan bahwa terdapat hubungan kuat antara partisipasi masyarakat dengan keberlanjutan sosial-budaya di sekitar kawasan ekowisata religi (islami) Kampung Batusuhunan. Hal tersebut ditunjukkan dengan tingginya tingkat partisipasi masyarakat dalam melestarikan dan menjaga situs-situs sejarah dan nilai-nilai luhur yang ada, serta berperan aktif dalam mengikuti kegiatan-kegiatan yang diselenggarakan oleh RT setempat maupun 
pengelola ekowisata inti. Walaupun demikian, tidak menampik bahwa terdapat konflik yang terjadi di masyarakat sekitar kawasan ekowisata meskipun hanya konflik laten. Hal tersebut terjadi karena terdapat kecemburuan sosial dalam pengambilan keuntungan dalam pengelolaan tempat parkir untuk pengunjung yang datang ke tempat ekowisata.

3. Berdasarkan penelitian ini ditemukan bahwa terdapat hubungan cukup antara partisipasi masyarakat dengan keberlanjutan ekonomi (kemandirian ekonomi lokal) di sekitar kawasan ekowisata religi (islami) Kampung Batusuhunan. Hal tersebut dapat terlihat dengan tingkat partisipasi masyarakat yang tinggi tetapi masih belum mempunyai usaha, adapun masyarakat yang mempunyai usaha baik perseorangan maupun bersama jarang sekali yang diperjual-belikan di sekitar kawasan ekowisata. hal tersebut dikarenakan belum terdapat regulasi dan kebijakan yang dapat mengembangkan usaha masyarakat dan menarik peminat pengunjung dalam ekowisata. sementara itu tidak ditemukannya hubungan partisipasi dengan taraf hidup masyarakat sekitar kawasan ekowisata, dikarenakan pengelolaan ekowisata yang ada belum mampu menambah pendapatan yang signifikan bagi keseluruhan masyarakat sekitar kawasan ekowisata.

4.Berdasarkan penelitian ini ditemukan bahwa pengembangan ekowisata religi belum sepenuhnya menguatkan ekonomi pedesaan serta pemerintah daerah yang belum memaksimalkan pembangunan ekonomi masyarakat dari pinggiran. Hal tersebut terbukti dengan semakin merosotnya pengembangan ekowisata religi seperti fasilitas yang tidak terawat belum meratanya pendapatan ekonomi masyarakat dibidang ekowisata serta banyaknya kesenjangan sosial antara warga khusunya RT 14 dengan RT lainnya.

\section{Saran}

1. Untuk Pemerintah Daerah, diharapkan dapat meningkatkan interaksi dan komunikasi dengan pengelola ekowisata yang ada di Kampung Batusuhunan dengan harapan dapat mengidentifikasi kekurangan-kekurangan dalam pengelolaan ekowisata tersebut, serta pemerintah mampu membawa para pengembang/stakeholder untuk membangun tempat ekowisata yang lebih terkelola sehingga dapat menarik minat wisatawan yang berkunjung dan mampu mengubah taraf hidup masyarakat ke arah yang lebih baik.

2. Untuk masyarakat, khususnya para pengelola inti dan pengelola anggota diharapkan dapat terus mempertahankan tingkat partisipasinya, terutama pada tahap perncanaan, pelaksanaan dan evaluasi. Partisipasi pada tahap perencanaan akan memberikan manfaat berupa aspirasi yang tersalurkan sehingga meminimalisir konflik laten, partisipasi pada tahap pelaksanaan akan memberikan manfaat pengetahuan kepada masyarakat, terutama masukan dan pertimbangan yang baik dalam pengelolaan ekowisata. Partisipasi pada tahap evaluasi juga akan memberikan manfaat pada pengelola, tentunya diikuti dengan perbaikan kualitas pengelolaan yang akan memberikan keuntungan bagi masyarakat Kampung Batusuhunan.

3. Untuk akademisi, diperlukan program-program yang dapat menambah pengetahuan dalam pengelolaan sampah yang baik, serta diperlukannya penelitian lebih lanjut mengenai modal sosial, perubahan sosial yang terjadi di Kampung Batusuhunan terkait pembukaan ekowisata religi (islami).

\section{DAFTAR PUSTAKA}

Adelia A. 2009. Persepsi Masyarakat Terhadap Pengembangan Kawasan Ekowisata Islami Curug Cigangsa (Kampung Batusuhunan, Kelurahan Surade, Kabupaten Sukabumi, Provinsi Jawa Barat) [skripsi]. [Internet]. Tersedia pada: http://repository.ipb.ac.id/bitstream/handle/1234 $56789 / 58728 /$ I12aad1.pdf? sequence=12\&isAllo wed $=\mathrm{y}$

Blackwell. 2007. Motivations for Religious Tourism, Pilgrimage, Festivals and Events. Leeds (GBR). Leeds Metropolitan University.

CIFOR. 2004. Pembangunan Pariwisata Berbasis Masyarakat. CIFOR, Bogor.

Cohen JM dan Uphoff NT. 1979. Participation's Place in Rural Development: Seeking Clarity Through Specificity. [Diunduh 15 Oktober 2015]. Tersedia

pada:www.researchgate.net/profile/Norman_Uph off/publication/4897194 Participation\%27s Plac e in Rural Development_Seeking_Clarity_Thro ugh Specificity/links/54e5f44d0cf2cd2e028b535 $\mathrm{d}$ ? ev=pub_ext_doc_dl\&origin=publication_detai 1\&inViewer=true. 
Direktorat Jendral Cipta Karya, Kementerian Pekerjaan Umum dan Perumahan Rakyat. 2016. Konsep Pembangunan Berkelanjutan [Internet]: Tersedia pada: http://www.kotahijau.id/knowledge/detail/pemba ngunan-berkelanjutan

Ditjen Pengembangan Destinasi Pariwisata, Departemen Kebudayaan dan Pariwisata dan WWF Indonesia. 2009. Prinsip dan Kriteria Ekowisata Berbasis Masyarakat. Jakarta (ID): Departemen Kebudayaan dan Pariwisata dan WWF Indonesia.

Fandeli C, Mukhlison. 2000. Kebijakan Pengembangan Ekowisata: Pengembangan Ekowisata dengan paradigma baru pengelolaan Areal Konservasi. Fakultas Kehutanan UGM. Yogyakarta: UKSDA Jogya dan pustaka belajar.

Harun, Rochajat. 2008. Manajemen Pariwisata. Bandung (ID): Universitas Pendidikan Indonesia.

Hijriati E, Rina Mardiana. 2014. Pengaruh Ekowisata Berbasis Masyarakat Terhadap Perubahan Kondisi Ekologi, Sosial dan Ekonomi di Kampung Batusuhunan Sukabumi. Jurnal Sosiologi Pedesaan. [Internet]. 2(3): 146159.[diunduh 2016 Oktober 9] tersedia pada : http://journal.ipb.ac.id/index.php/sodality/article/ download/9422/7385

Kementerian Kebudayaan dan Pariwisata Republik Indonesia. 2003. Ekowisata Prinsip dan Kriteria. Kementerian Kebudayaan dan Pariwisata Republik Indonesia dan Indecon. Jakarta[ID].

Kementerian Pariwisata Republik Indonesia. 2016. Pedoman Destinasi Pariwisata Berkelanjutan. Jakarta [ID]

Kodhyat, H. 1996. Sejarah Pariwisata dan Perkembangannya di Indonesia. Jakarta[ID]: Gramedia Widiasarana Indonesia.

Lugiarti, Eppy. 2004. Peningkatan Partisipasi Masyarakat dalam Proses Perencanaan Program Pengembangan Masyarakat di Komunitas Desa Cijayanti. [Tesis]. Bogor (ID): Sekolah Pascasarjana, Institut Pertanian Bogor.

Mathieson and Wall. 1982. Tourism: Economics, Physical and Social Impacts. New York: Long Man.

Muntasib $\mathrm{H}$ et al. 2014. Rekreasi Alam dan Ekowisata. Bogor (ID): IPB Pr.
Nasdian FT. 2014. Pengembangan Masyarakat. Jakarta (ID): Yayasan Pustaka Obor Indonesia.

Nugroho. 2011. Ekowisata dan Pembangunan Berkelanjutan. Yogyakarta [ID] Pustaka Pelajar

Sarwono, J. 2006. Metode Penelitian Kuantitatif dan Kualitatif. Yogyakarta (ID): Graha Ilmu.

Satria D. 2016. Strategi Pengembangan Ekowisata Berbasis Ekonomi Lokal Dalam Rangka Program Pengentasan Kemiskinan di Kabupaten Malang. Jurnal of Indonesian Applied Economics [Internet]. 3(1): 37-47. [diunduh 2016 November 21] Tersedia pada: jiae.ub.ac.id > Home > Vol 3, No 1 (2009) > Satria

Slamet, Y. 1992, Pembangunan Masyarakat Berwawasan Partisipasi, Sebelas Maret University Press, Surakarta.

Slamet, M. 2003. Membentuk Pola Perilaku Manusia Pembangunan. IPB Press. Bogor.

Sujali. 1996. Peranan Kepariwisataan Dalam Pengembangan Daerah (Kasus Daerah Klaten). Forum Geografi Jurnal Fakultas Geografi. UMS No 18.

Suwantoro G. 1997. Dasar-Dasar Pariwisata. Yogyakarta [ID]: Andi Publishing.

Swarbrooke, J. 1998. Sustainable Tourism Management. London[UK] : CABI Publishing.

Timothy, D.J., "Participatory Planning a View of Tourism in Indonesia," Annuals Review of Tourism Research, XXVI (2) 1999.

Untari R. 2009. Strategi Pengembangan Ekowisata Berbasis Masyarakat di Zona Wisata Bogor Barat Kabupaten Bogor [tesis]. [internet]. Tersedia pada:

http://repository.ipb.ac.id/bitstream/handle/1234567 89/43810/2009run.pdf?sequence $=1 \&$ isAllowed $=$ ע

WALHI. 1995. Strategi Keanekaragaman Hayati Global. Jakarta [ID]: PT Gramedia Pustaka Utama.

WWF. 2009. Indonesia Prinsip dan Kriteria Ecotourism [Internet]. [diunduh 2016 September 15]. Tersedia pada: http://awsassets.wwf.or.id/downloads/wwf indo nesia prinsip dan kriteria ecotourism_jan 200 9.pdf 
Yoeti, OA. 1991. Pengantar Ilmu Pariwisata. Bandung [ID]: Angkasa

Yoeti, OA. 2006. Perencanaan dan Pengembangan Pariwisata. Jakarta [ID]: Pradnya Paramitha.

Yoeti, OA. 2008. Ekonomi Pariwisata: Introduksi, Informasi dan Implementasi. Jakarta[ID]: Kompas. 